\title{
Assessment of Serum Zinc Levels of Patients with Thalassemia Compared to Their Siblings
}

\author{
Mohamed El Missiry, ${ }^{1}$ Mohamed Hamed Hussein, ${ }^{1}$ Sadaf Khalid, ${ }^{1}$ Naila Yaqub, ${ }^{2}$ \\ Sarah Khan, ${ }^{2}$ Fatima Itrat, ${ }^{2}$ Cornelio Uderzo, ${ }^{1}$ and Lawrence Faulkner ${ }^{1}$ \\ ${ }^{1}$ Cure2Children Foundation, Via Marconi 30, 50131 Florence, Italy \\ ${ }^{2}$ Children's Hospital Pakistan Institute of Medical Sciences, Islamabad, Pakistan \\ Correspondence should be addressed to Mohamed El Missiry; mohamed.elmissiry@cure2children.org
}

Received 31 January 2014; Accepted 5 August 2014; Published 14 August 2014

Academic Editor: Aurelio Maggio

Copyright (C) 2014 Mohamed El Missiry et al. This is an open access article distributed under the Creative Commons Attribution License, which permits unrestricted use, distribution, and reproduction in any medium, provided the original work is properly cited.

\begin{abstract}
Zinc $(\mathrm{Zn})$ is essential for appropriate growth and proper immune function, both of which may be impaired in thalassemia children. Factors that can affect serum $\mathrm{Zn}$ levels in these patients may be related to their disease or treatment or nutritional causes. We assessed the serum $\mathrm{Zn}$ levels of children with thalassemia paired with a sibling. Zn levels were obtained from 30 children in Islamabad, Pakistan. Serum Zn levels and anthropometric data measures were compared among siblings. Thalassemia patients' median age was 4.5 years (range 1-10.6 years) and siblings was 7.8 years (range 1.1-17 years). The median serum Zn levels for both groups were within normal range: $100 \mu \mathrm{g} / \mathrm{dL}(10 \mu \mathrm{g} / \mathrm{dL}-297 \mu \mathrm{g} / \mathrm{dL})$ for patients and $92 \mu \mathrm{g} / \mathrm{dL}(13 \mu \mathrm{g} / \mathrm{dL}-212 \mu \mathrm{g} / \mathrm{dL})$ for siblings. There was no significant difference between the two groups. Patients' serum Zn values correlated positively with their corresponding siblings $(r=0.635, P<0.001)$. There were no correlations between patients' $\mathrm{Zn}$ levels, height for age Z-scores, serum ferritin levels, chelation, or blood counts (including both total leukocyte and absolute lymphocyte counts). Patients' serum Zn values correlated with their siblings' values. In this study, patients with thalassemia do not seem to have disease-related $\mathrm{Zn}$ deficiency.
\end{abstract}

\section{Introduction}

Zinc $(\mathrm{Zn})$ is an essential element for cell growth, differentiation, and survival. It is a structural element of many proteins [1]. Zinc affects growth in children. It is known that adequate zinc levels in the body are essential for maintaining suitable levels of growth hormone and insulin-like growth factor in the body [2]. Impairment of zinc levels will consequently lead to growth hormone decrease. Zinc supplement is given to children on growth hormone replacement therapy. In addition, zinc is important for nucleic acid synthesis, cell division, and metabolism of lipids, proteins and carbohydrates. It is also essential in bone homeostasis and bone growth as well as in the maintenance of connective tissues. Decreased Zn may compromise growth and immune functions $[2,3]$.

$\mathrm{Zn}$ is known to be important for the integrity of the immune system, although its role and mechanism of action are not fully understood $[1,4-6]$. Zn deficiency affects the adaptive immune system and results in thymus atrophy, lymphopenia, and impaired lymphocyte function $[4,7,8]$.

Zinc deficiency is prevalent in children of developing countries where food is often vegetable-based and rarely includes animal products. Zinc is easily absorbed with animal proteins, while excess plant meals lead to decreased zinc absorption due to its binding to phytates $[9,10]$. In such countries, $\mathrm{Zn}$ deficiency results in growth retardation, hypogonadism, and increased mortality and morbidly from infection-related diarrhea and pneumonia due to compromised immune function $[4,9]$.

Despite deficits of several specific micronutrients reported in children with thalassemia major, $\mathrm{Zn}$ studies yielded conflicting results $[7,11,12]$. Several factors contribute to zinc deficiency in thalassemia. One of these most important factors is chelation therapy. Chelators, namely, deferoxamine and deferiprone, may contribute to $\mathrm{Zn}$ deficiency in thalassemia as they tend to eliminate positive divalent ions, like 
iron and $\mathrm{Zn}$, into urine $[7,13,14]$. On the other side, some studies showed no significant correlation between zinc level and short stature, serum ferritin level, desferrioxamine dose, age at first blood transfusion, and chelation therapy [7]. Zinc can be normal in some patients especially those who are on regular blood transfusions $[7,11,12]$. What is notable that these studies were performed on adequately treated patients subjects which is not the case in many thalassemia affected areas where access to treatment is not always possible.

In the present study, we aimed to assess serum $\mathrm{Zn}$ levels in patients with thalassemia and their siblings in a lower middle income country, namely, Pakistan (http://data.worldbank .org/country/pakistan), to determine whether Zn deficiency is present and, if so, if it is related to the disease per se, the use of chelation or to nutritional factors.

\section{Patients and Methods}

The present study was performed at the Children's Hospital of the Pakistan Institute of Medical Sciences (PIMS), Islamabad, Pakistan, between June 2009 and February 2012. A total of 30 patients with $\beta$-thalassemia major and 30 siblings were included. Parental informed consent was obtained. The following data were obtained from the patients' clinical file records: blood transfusion history, last ferritin measurement, onset of chelation therapy and type of chelation used, and infection profile. In addition to serum $\mathrm{Zn}$ levels, anthropometric measures such as height, weight, and body mass index (BMI) $\left(\right.$ BMI $=$ weight $(\mathrm{kg}) /$ height $^{2}\left(\mathrm{~m}^{2}\right)$ were obtained).

Sampling and processing: Three $\mathrm{mL}$ of peripheral venous blood was withdrawn from each patient and sibling in the early morning, three hours before having breakfast. The samples were left for 20 minutes to clot at room temperature and then centrifuged at $2000 \times \mathrm{g}$ for 10 minutes, and sera were separated and put into aliquots which were stored at $-70^{\circ} \mathrm{C}$ till they were analyzed by atomic absorption spectrometer (AAS; AA300). $\mathrm{Zn}$ normal values were estimated to lie between 65 and $120 \mu \mathrm{g} / \mathrm{dL}$ [15].

Statistical analyses were performed by parametric single and paired $t$-test (after the run of normality test to check that data is normally distributed) and Pearson's correlation coefficient test. A $P$ value $\leq 0.05$ was considered to be statistically significant.

\section{Results}

Median patient age was 4.5 years (ranging from 1 to 10.6 years) and median sibling age was 7.3 years (ranging from 1.1 to 17 years). Patients' serum $\mathrm{Zn}$ ranged from $10 \mu \mathrm{g} / \mathrm{dL}$ to $297 \mu \mathrm{g} / \mathrm{dL}$ (median $100 \mu \mathrm{g} / \mathrm{dL}$ ), while siblings' serum $\mathrm{Zn}$ ranged from $13 \mu \mathrm{g} / \mathrm{dL}$ to $212 \mu \mathrm{g} / \mathrm{dL}$ (median $92 \mu \mathrm{g} / \mathrm{dL}$ ) (Figure 1). There were no significant differences in Zn levels between the patients and their corresponding siblings $(P=0.19)$ on matched pair analysis (Table 1). However, it was found that $\mathrm{Zn}$ levels were significantly correlated between patients with their corresponding siblings $(r$ correlation coefficient $=0.63$, $P<0.0001$ ) (Figure 2).
After measuring the height for age $Z$-scores for the 30 patients with thalassemia, it was found that heights ranged between -4.2 at minimum and 1.09 at maximum (median = $-1.5)$. Height for age $Z$-scores and $Z n$ levels did not correlate $(r=0.05)$.

For siblings, the median height for age $Z$-scores was -1.2 and ranged from -3.78 to 2.6 (median $=-1.2$ ). A comparison of patient height for age $Z$-scores with corresponding values for siblings revealed that patients' $Z$-scores levels were significantly lower than corresponding siblings $(P=0.02)$. Correlation between the two groups was weakly positive $(r=$ $0.4)$, and pairing between the two groups was statistically significant $(P=0.01)$.

The median patient serum ferritin level was $2065 \mathrm{ng} / \mathrm{mL}$ (range: $5475 \mathrm{ng} / \mathrm{mL}-81.15 \mathrm{ng} / \mathrm{mL}$ ) and showed no correlation with patients' Zn level $(P=0.7)$.

Regular chelation therapy was used by 14 patients: 7 cases were on deferasirox and 7 cases on desferrioxamine, while 16 cases received no chelation therapy. No significant difference in $\mathrm{Zn}$ levels was found between chelated and nonchelated groups (median zinc levels were $103.5 \mu \mathrm{g} / \mathrm{dL}$ and $96 \mu \mathrm{g} / \mathrm{dL}$ for chelated and nonchelated patients, respectively, $P=0.63$ ). There was also no significant difference in zinc values between patients on desferrioxamine and those on deferasirox (median zinc levels were $96 \mu \mathrm{g} / \mathrm{dL}$ and $102 \mu \mathrm{g} / \mathrm{dL}$ for patients with desferrioxamine and deferasirox, respectively, $P=0.37$ ).

Absolute lymphocytic count (ALC) ranged between 817 and 9040 microL, with a median of 3882 microL. No correlation was found between patients' $\mathrm{Zn}$ values and ALC $(r=0.36)$.

\section{Discussion}

Zinc is an essential element for growth and immunity. In this study we aimed to compare serum $\mathrm{Zn}$ levels between thalassemia patients and their healthy siblings as to assess whether a possible deficiency is influenced by the disease itself or by nutritional and familial/environmental causes.

Patients' and siblings' $\mathrm{Zn}$ median values were within the normal range (median values were $100 \mu \mathrm{g} / \mathrm{dL}$ and $92 \mu \mathrm{g} / \mathrm{dL}$ for patients and siblings, resp.) with no significant difference (patients' serum $\mathrm{Zn}$ median value was $100 \mu \mathrm{g} / \mathrm{dL}$ versus $92 \mu \mathrm{g} / \mathrm{dL}$ for siblings) (Figure 1). This finding is in agreement with studies by Rea et al. (1984) [12] and Donma et al. (1990) [11] who noted that the serum Zn levels of patients with thalassemia can be higher than normal [11, 12]. Among the 30 siblings in this study, 18 were carriers for beta thalassemia and 12 were not with no significant differences between the two groups, suggesting that $\mathrm{Zn}$ status is not related to thalassemia - the disease itself or trait. The patients' $\mathrm{Zn}$ values in this study correlated significantly with corresponding siblings $(r$ correlation coefficient $=0.63, P<0.0001)$ (Figure 2$)$ suggesting that $\mathrm{Zn}$ level was not influenced by thalassemia or its treatment [7], but rather seems more likely related to familial factors either genetic or nutritional/environmental [7].

No correlation between $\mathrm{Zn}$ values and growth (height for age $Z$-scores) was observed in our patients. Similar results 
TABLE 1: (a) A collective table for the data of the patients: zinc level in $\mu \mathrm{g} / \mathrm{dL}$, sex (m: male, f: female), age (in years), height (in cm), height-age $z$-score, ferritin level (in $\mathrm{ng} / \mathrm{mL}$ ), chelation type, and ALC (in microL). (b) A collective table for the data of the patients: zinc level in $\mu \mathrm{g} / \mathrm{dL}$, sex (m: male, f: female), age (in years), height (in $\mathrm{cm}$ ), and height-age $z$-score.

(a)

\begin{tabular}{|c|c|c|c|c|c|c|c|c|}
\hline $\begin{array}{l}\text { Patient } \\
\text { number }\end{array}$ & $\begin{array}{c}\text { Zinc level } \\
(\mu \mathrm{g} / \mathrm{dL})\end{array}$ & Sex & Age (years) & Height $(\mathrm{cm})$ & Height-age $z$-score & Ferritin $(\mathrm{ng} / \mathrm{mL})$ & Chelation & ALC (microL) \\
\hline 1 & 94 & $\mathrm{~m}$ & 2.6 & 84 & -1.33 & 694 & None & 6325 \\
\hline 2 & 58 & $\mathrm{~m}$ & 2.9 & 92 & -0.97 & 2527 & None & 6200 \\
\hline 3 & 68 & $\mathrm{f}$ & 5.3 & 100 & -2.29 & 3004 & Deferasirox & 3903 \\
\hline 4 & 297 & $\mathrm{~m}$ & 2.5 & 92 & -0.04 & 785 & None & 3891 \\
\hline 5 & 130 & $\mathrm{~m}$ & 1 & 72 & -2 & 641 & None & 7956 \\
\hline 6 & 66 & $\mathrm{~m}$ & 5.5 & 106 & -1.51 & 2129 & Deferoxamine & 2156 \\
\hline 7 & 102 & $\mathrm{f}$ & 2.5 & 91 & -1 & 2000 & Deferasirox & 8024 \\
\hline 8 & 80 & $\mathrm{f}$ & 8.8 & 122 & -1.57 & 3513 & Deferoxamine & 2340 \\
\hline 9 & 109 & $\mathrm{~m}$ & 3.8 & 88 & -4 & 1551 & None & 7526 \\
\hline 10 & 157 & $\mathrm{~m}$ & 4.4 & 106 & -1 & 2425 & Deferoxamine & 3872 \\
\hline 11 & 120 & $\mathrm{~m}$ & 8.2 & 115 & -2.31 & 1502 & Deferoxamine & 3008 \\
\hline 12 & 74 & $\mathrm{~m}$ & 2.5 & 89 & -1.17 & 616 & None & 4884 \\
\hline 13 & 127 & $\mathrm{~m}$ & 5.4 & 105 & -1.48 & 3810 & None & 3570 \\
\hline 14 & 75 & $\mathrm{f}$ & 4 & 95 & -1.79 & 1150 & None & 1700 \\
\hline 15 & 117 & $\mathrm{f}$ & 4.6 & 111 & 0.92 & 1804 & Deferasirox & 1218 \\
\hline 16 & 295 & $\mathrm{~m}$ & 1.9 & 81 & -1.6 & 850 & None & 9040 \\
\hline 17 & 88 & $\mathrm{~m}$ & 10.6 & 131 & -1.5 & 5475 & Deferasirox & 1160 \\
\hline 18 & 116 & $\mathrm{f}$ & 4 & 95 & -2 & 2836 & None & 2813 \\
\hline 19 & 17 & $\mathrm{~m}$ & 4.7 & 113 & 1.09 & 658 & None & 2592 \\
\hline 20 & 111 & $\mathrm{~m}$ & 5.6 & 109 & -1.18 & 2411 & Deferoxamine & 5002 \\
\hline 21 & 112 & $\mathrm{~m}$ & 7.1 & 114 & -1.53 & 1951 & None & 1353 \\
\hline 22 & 10 & $\mathrm{~m}$ & 1.6 & 72 & -4.2 & 81.15 & None & 817 \\
\hline 23 & 79 & $\mathrm{~m}$ & 2.2 & 83 & -1.9 & 2621 & None & 5490 \\
\hline 24 & 15 & $\mathrm{f}$ & 5 & 110 & 0.14 & 5036 & Deferoxamine & 1980 \\
\hline 25 & 97 & $\mathrm{f}$ & 10 & 124 & -2.32 & 706 & Deferasirox & 4312 \\
\hline 26 & 96 & $\mathrm{f}$ & 10.4 & 139 & -0.32 & 4487 & Deferoxamine & 3062 \\
\hline 27 & 120 & $\mathrm{~m}$ & 4.5 & 106 & -0.33 & 5054 & None & 3180 \\
\hline 28 & 105 & $\mathrm{f}$ & 7.4 & 117 & -1.41 & 1760 & Deferasirox & 4260 \\
\hline 29 & 98 & $\mathrm{~m}$ & 1.3 & 75 & -1.9 & 3812 & None & 5535 \\
\hline 30 & 260 & $\mathrm{~m}$ & 4.4 & 98 & -2.01 & 4100 & Deferasirox & 3944 \\
\hline
\end{tabular}

(b)

\begin{tabular}{lcccccc}
\hline $\begin{array}{l}\text { Sibling } \\
\text { number }\end{array}$ & $\begin{array}{c}\text { Zinc level } \\
(\mu \mathrm{g} / \mathrm{dL})\end{array}$ & Sex & Age (years) & Height $(\mathrm{cm})$ & Height-age $z$-score & Sibling carrier status \\
\hline Sibling of 1 & 25 & $\mathrm{f}$ & 12.0 & 143 & -1.23 & Not a carrier \\
Sibling of 2 & 75 & $\mathrm{~m}$ & 5.9 & 128 & 2.62 & Carrier \\
Sibling of 3 & 28 & $\mathrm{f}$ & 9.4 & 127 & -1.31 & Not a carrier \\
Sibling of 4 & 203 & $\mathrm{~m}$ & 6.2 & 108 & -1.85 & -1.8 \\
Sibling of 5 & 68 & $\mathrm{f}$ & 11.5 & 136 & -0.48 & Carrier \\
Sibling of 6 & 35 & $\mathrm{~m}$ & 2.4 & 89 & 0.74 & Carrier \\
Sibling of 7 & 151 & $\mathrm{f}$ & 1.1 & 77 & 0.95 & Not a carrier \\
Sibling of 8 & 89 & $\mathrm{~m}$ & 4.1 & 108 & -2.24 & Carrier \\
Sibling of 9 & 212 & $\mathrm{f}$ & 8.7 & 117 & -0.53 & Carrier \\
Sibling of 10 & 194 & $\mathrm{f}$ & 12.4 & 150 & & Carrier
\end{tabular}


(b) Continued.

\begin{tabular}{|c|c|c|c|c|c|c|}
\hline $\begin{array}{l}\text { Sibling } \\
\text { number }\end{array}$ & $\begin{array}{c}\text { Zinc level } \\
(\mu \mathrm{g} / \mathrm{dL})\end{array}$ & Sex & Age (years) & Height $(\mathrm{cm})$ & Height-age $z$-score & Sibling carrier status \\
\hline Sibling of 11 & 138 & $\mathrm{~m}$ & 6.9 & 110 & -2.16 & Not a carrier \\
\hline Sibling of 12 & 72 & $\mathrm{~m}$ & 6.9 & 119 & -0.41 & Carrier \\
\hline Sibling of 13 & 81 & $\mathrm{~m}$ & 1.5 & 75 & -2.5 & Not a carrier \\
\hline Sibling of 14 & 82 & $\mathrm{~m}$ & 12.0 & 140 & -1.26 & Carrier \\
\hline Sibling of 15 & 98 & $\mathrm{f}$ & 2.6 & 144 & -1.51 & Not a carrier \\
\hline Sibling of 16 & 90 & $\mathrm{f}$ & 5.3 & 104 & -1.39 & Carrier \\
\hline Sibling of 17 & 79 & $\mathrm{f}$ & 17.0 & 149 & -2.07 & Carrier \\
\hline Sibling of 18 & 98 & $\mathrm{~m}$ & 14.1 & 150 & -1.8 & Not a carrier \\
\hline Sibling of 19 & 42 & $\mathrm{f}$ & 9.0 & 137 & 0.74 & Not a carrier \\
\hline Sibling of 20 & 94 & $\mathrm{f}$ & 7.5 & 118 & -1.03 & Not a carrier \\
\hline Sibling of 21 & 107 & $\mathrm{f}$ & 11.9 & 132 & -2.7 & Carrier \\
\hline Sibling of 22 & 13 & $\mathrm{~m}$ & 3.2 & 89 & -2.18 & Carrier \\
\hline Sibling of 23 & 96 & $\mathrm{~m}$ & 11.2 & 134 & 1.5 & Carrier \\
\hline Sibling of 24 & 13 & $\mathrm{f}$ & 7.2 & 124 & 0.39 & Carrier \\
\hline Sibling of 25 & 113 & $\mathrm{~m}$ & 8.0 & 106 & -3.78 & Carrier \\
\hline Sibling of 26 & 87 & $\mathrm{f}$ & 2.4 & 90 & -0.01 & Carrier \\
\hline Sibling of 27 & 123 & $\mathrm{f}$ & 7.2 & 130 & 1.45 & Carrier \\
\hline Sibling of 28 & 114 & $\mathrm{f}$ & 1.2 & 73 & -1.1 & Carrier \\
\hline Sibling of 29 & 103 & $\mathrm{f}$ & 9.2 & 140 & 0.98 & Not a carrier \\
\hline Sibling of 30 & 180 & $\mathrm{f}$ & 12.0 & 138 & -1.94 & Not a carrier \\
\hline
\end{tabular}

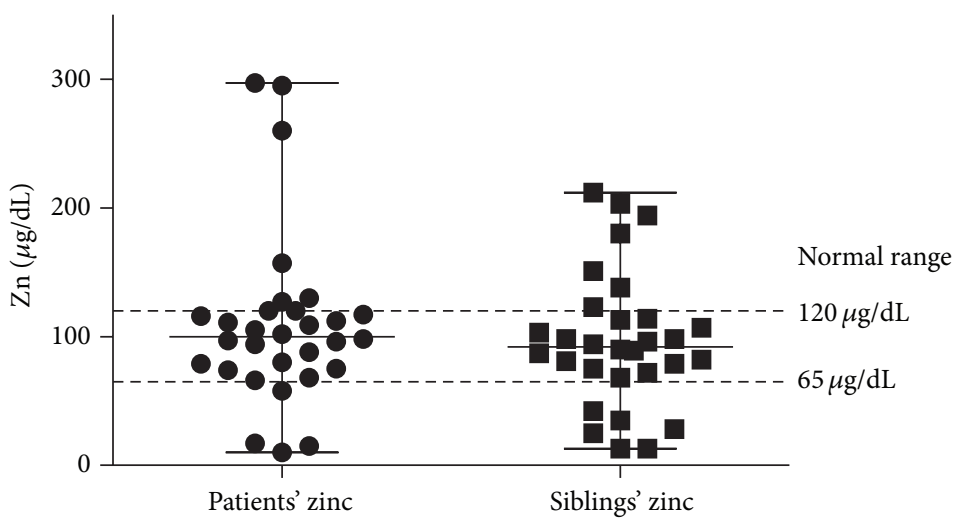

FIGURE 1: Comparison between serum Zn levels for patients and their corresponding siblings. Median levels were within normal range: $100 \mu \mathrm{g} / \mathrm{dL}(10 \mu \mathrm{g} / \mathrm{dL}-297 \mu \mathrm{g} / \mathrm{dL})$ for patients and $92 \mu \mathrm{g} / \mathrm{dL}(13 \mu \mathrm{g} / \mathrm{dL}-212 \mu \mathrm{g} / \mathrm{dL})$ for siblings.

have been found in several other studies; thus, it is assumed that a $\mathrm{Zn}$ deficiency is not related to short stature $[7,16]$. However, in a study by Kyriakou and Skordis (2009) [17], the authors proposed that $\mathrm{Zn}$ deficiency could be a concomitant factor for growth failure among patients with thalassemia [17]. As patients were found to have significant lower heightfor-age compared to their siblings, however there are other concomitant variables such as chronic anemia, iron overloadrelated endocrine problems, and impaired bone growth which play an important role [18-20]. In our study zinc levels did not seem to differ among siblings suggesting that Zn deficiency may not play a significant role in growth differences often observed between thalassemic children and their brothers or sisters.

It appears that elevated ferritin levels are inversely related to $\mathrm{Zn}$ levels so that as ferritin increases, $\mathrm{Zn}$ decreases. However, in this study, the correlation was not statically significant. Decreased zinc levels or increased ferritin values have been previously reported $[7,21]$ and might be explained by inadequacy of clinical care and proper management affecting independently both ferritin and nutritional $\mathrm{Zn}$ levels.

With the limitation of a small sample size, in our study chelation therapy did not seem to affect zinc levels. Deferoxamine and deferiprone have been reported to also chelate and 


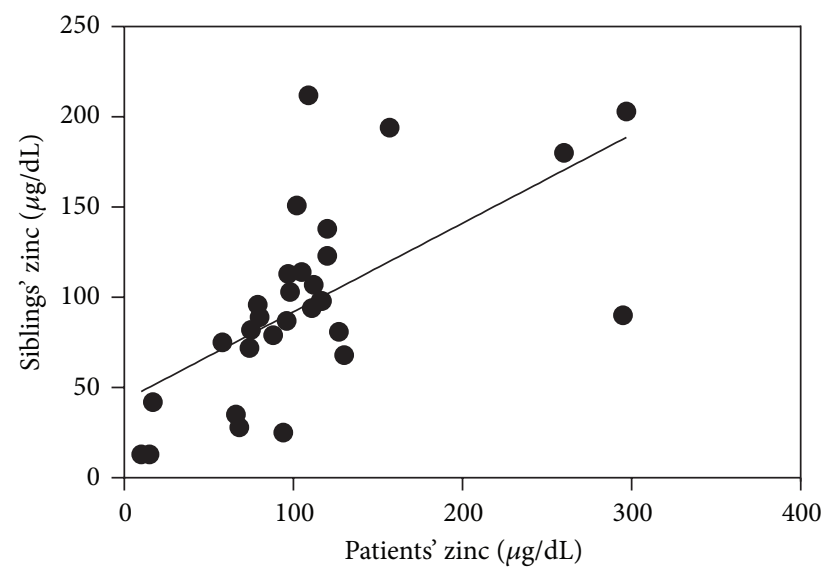

Figure 2: Correlation between patients' serum $\mathrm{Zn}$ values. Levels correlated positively with corresponding $(r=0.635, P<0.001)$.

eliminate zinc into urine, while for deferasirox, which has a lower affinity for divalent zinc, this seems not to be the case $[7,13,14]$.

Several studies have assumed that $\mathrm{Zn}$ is important to maintain intact lymphocytic function and counts $[4,7]$. Fraker and King (2004) [8] found that a Zn deficiency led to lymphopenia [8]. In conclusion, this study showed that patients with thalassemia do not seem to be prone to $\mathrm{Zn}$ deficiency. Patients' serum $\mathrm{Zn}$ values correlated with their sibling suggesting that serum $\mathrm{Zn}$ levels are possibly more influenced by familial and environmental factors rather than by thalassemia per se or its treatment.

\section{Abbreviations \\ ALC: Absolute lymphocytic count \\ BMI: Body mass index \\ CMV: Cytomegalovirus \\ IL-2: Interleukin 2 \\ IL-10: Interleukin 10 \\ Treg: T regulatory cells \\ Zn: Zinc.}

\section{Conflict of Interests}

The authors declare that there is no conflict of interests regarding the publication of this paper.

\section{Acknowledgments}

The authors would like to thank the patients and their families for showing cooperativeness and they acknowledge the support of Cure2Children foundation (C2C), Florence, Italy, and Pakistani-Italian Debt-for-Development Swap Agreement (PIDSA), Islamabad, Pakistan, for the support of the study. Special thanks are due to Assistant Adjunct Professor of Nursing, Julia Challinor, RN, Ph.D., University of California, San Francisco, USA, for revising this paper.

\section{References}

[1] T. Hirano, M. Murakami, T. Fukada, K. Nishida, S. Yamasaki, and T. Suzuki, "Roles of zinc and zinc signaling in immunity: zinc as an intracellular signaling molecule," Advances in Immunology, vol. 97, pp. 149-176, 2008.

[2] R. S. MacDonald, "The role of zinc in growth and cell proliferation," Journal of Nutrition, vol. 130, pp. 1500S-1508S, 2000.

[3] J. Brandão-Neto, V. Stefan, B. B. Mendonça, W. Bloise, and A. V. B. Castro, "The essential role of zinc in growth," Nutrition Research, vol. 15, pp. 335-358, 1995.

[4] M. Yu, W.-W. Lee, D. Tomar et al., "Regulation of T cell receptor signaling by activation-induced zinc influx," The Journal of Experimental Medicine, vol. 208, no. 4, pp. 775-785, 2011.

[5] J. L. Kadrmas and M. C. Beckerle, "The LIM domain: from the cytoskeleton to the nucleus," Nature Reviews Molecular Cell Biology, vol. 5, no. 11, pp. 920-931, 2004.

[6] G. Moshtaghi-Kashanian, A. Gholamhoseinian, A. Hoseinimoghadam, and S. Rajabalian, "Splenectomy changes the pattern of cytokine production in $\beta$-thalassemic patients," Cytokine, vol. 35, no. 5-6, pp. 253-257, 2006.

[7] M. Mehdizadeh, G. Zamani, and S. Tabatabaee, "Zinc status in patients with major $\beta$-thalassemia," Pediatric Hematology and Oncology, vol. 25, no. 1, pp. 49-54, 2008.

[8] P. J. Fraker and L. E. King, "Reprogramming of the immune system during zinc deficiency," Annual Review of Nutrition, vol. 24, pp. 277-298, 2004.

[9] M. Y. Yakoob, E. Theodoratou, A. Jabeen et al., "Preventive zinc supplementation in developing countries: impact on mortality and morbidity due to diarrhea, pneumonia and malaria," $B M C$ Public Health, vol. 11, no. 3, article S23, 2011.

[10] R. S. Gibson and E. L. Ferguson, "Nutrition intervention strategies to combat zinc deficiency in developing countries," Nutrition Research Reviews, vol. 11, no. 1, pp. 115-131, 1998.

[11] O. Donma, S. Gunbey, and M. A. M. M. tas Donma, "Zinc, copper, and magnesium concentrations in hair of children from southeastern Turkey," Biological Trace Element Research, vol. 24, no. 1, pp. 39-47, 1990.

[12] F. Rea, L. Perrone, A. Mastrobuono, G. Toscano, and M. D'Amico, "Zinc levels of serum, hair and urine in homozygous beta-thalassemic subjects under hypertransfusional treatment," Acta Haematologica, vol. 71, no. 2, pp. 139-142, 1984.

[13] R. Galanello, "Deferiprone in the treatment of transfusiondependent thalassemia: a review and perspective," Therapeutics and Clinical Risk Management, vol. 3, no. 5, pp. 795-805, 2007.

[14] M. D. Cappellini, "Exjade (deferasirox, ICL670) in the treatment of chronic iron overload associated with blood transfusion," Therapeutics and Clinical Risk Management, vol. 3, no. 2, pp. 291-299, 2007.

[15] M. Hambidge, "Human zinc deficiency," Journal of Nutrition, vol. 130, no. 5, pp. 1344S-1349S, 2000.

[16] G. J. Fuchs, P. Tienboon, S. Linpisarn et al., "Nutritional factors and thalassaemia major," Archives of Disease in Childhood, vol. 74, no. 3, pp. 224-227, 1996.

[17] A. Kyriakou and N. Skordis, "Thalassaemia and aberrations of growth and puberty," Mediterranean Journal of Hematology and Infectious Diseases, vol. 1, no. 1, 2009.

[18] V. de Sanctis, A. Eleftheriou, and C. Malaventura, "Prevalence of endocrine complications and short stature in patients with thalassaemia major: a multicenter study by the Thalassaemia International Federation (TIF)," Pediatric Endocrinology Reviews, vol. 2, supplement 2, pp. 249-255, 2004. 
[19] C. Theodoridis, V. Ladis, A. Papatheodorou et al., "Growth and management of short stature in thalassaemia major," Journal of Pediatric Endocrinology and Metabolism, vol. 11, no. 3, pp. 835844, 1998.

[20] Guidelines for the clinical management of thalassemia, 2008.

[21] A. Mahyar, P. Ayazi, A. A. Pahlevan, H. Mojabi, M. R. Sehhat, and A. Javadi, "Zinc \& copper status in children with Beta-thalassemia major," Iranian Journal of Pediatrics, vol. 20, pp. 297302, 2010. 


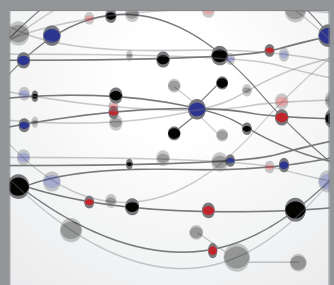

The Scientific World Journal
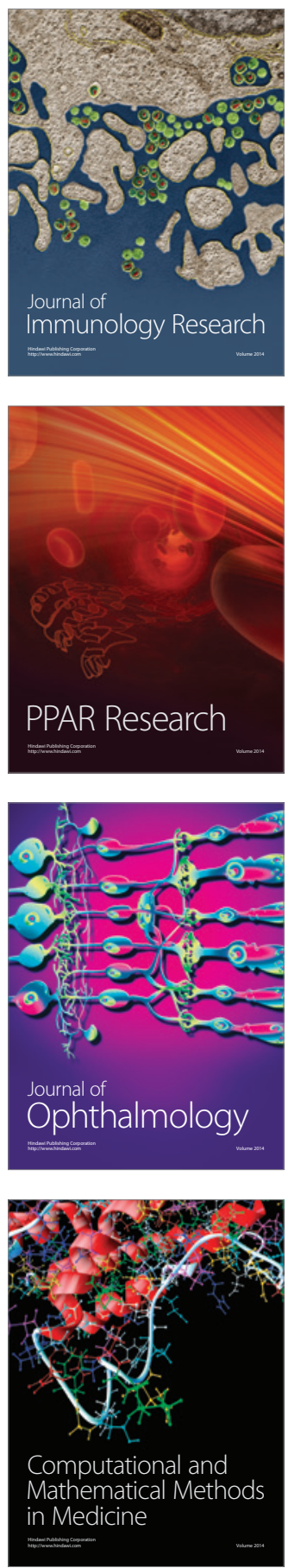

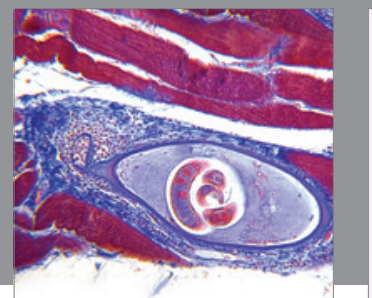

Gastroenterology

Research and Practice
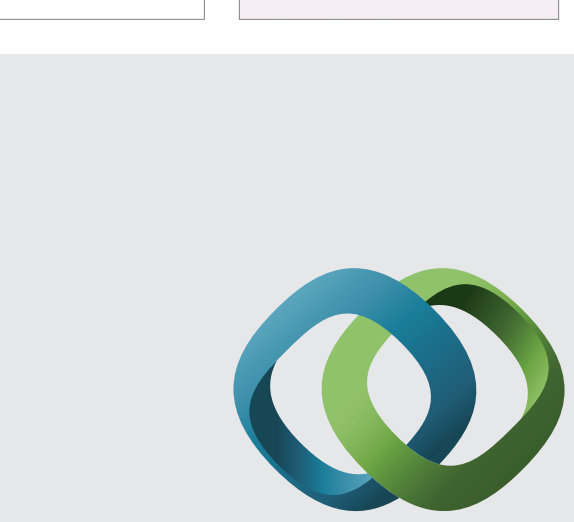

\section{Hindawi}

Submit your manuscripts at

http://www.hindawi.com
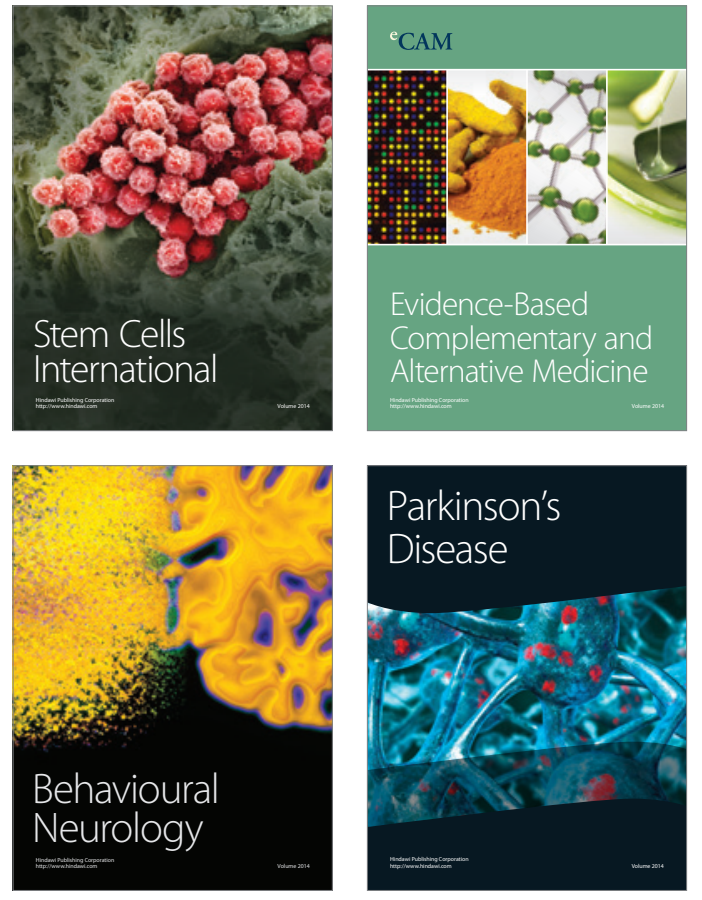
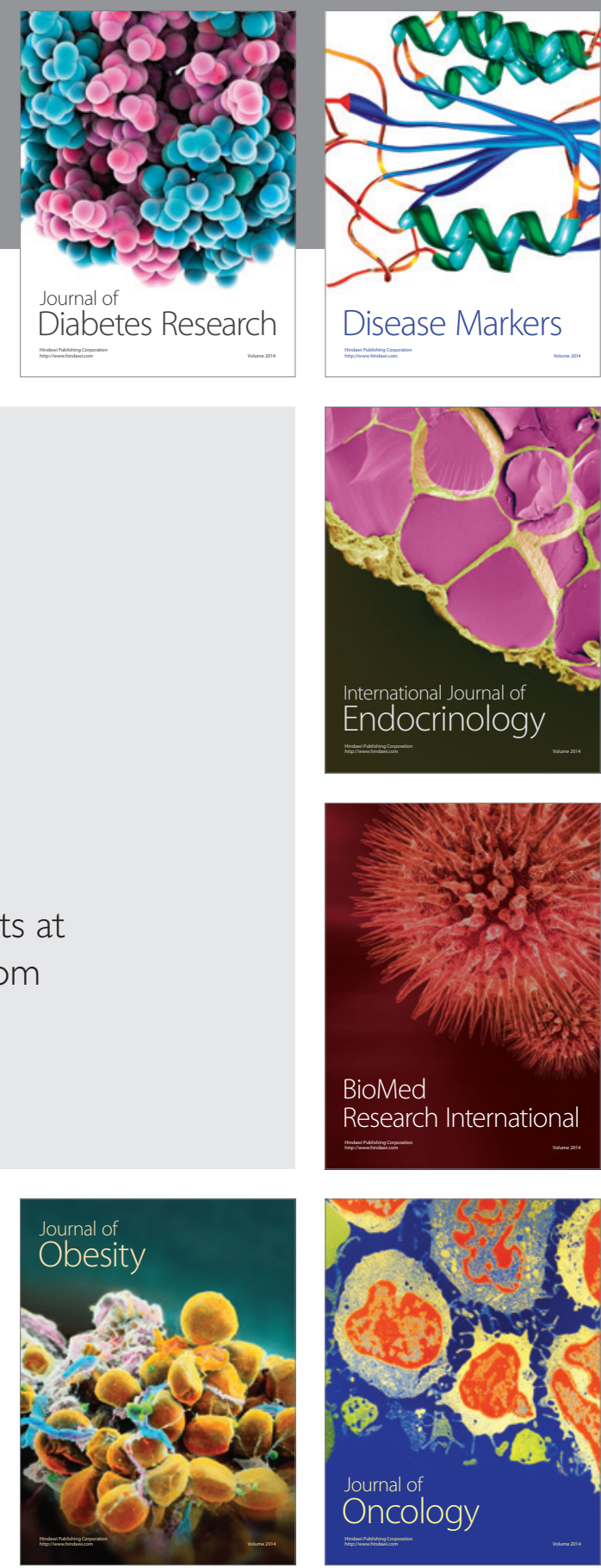

Disease Markers
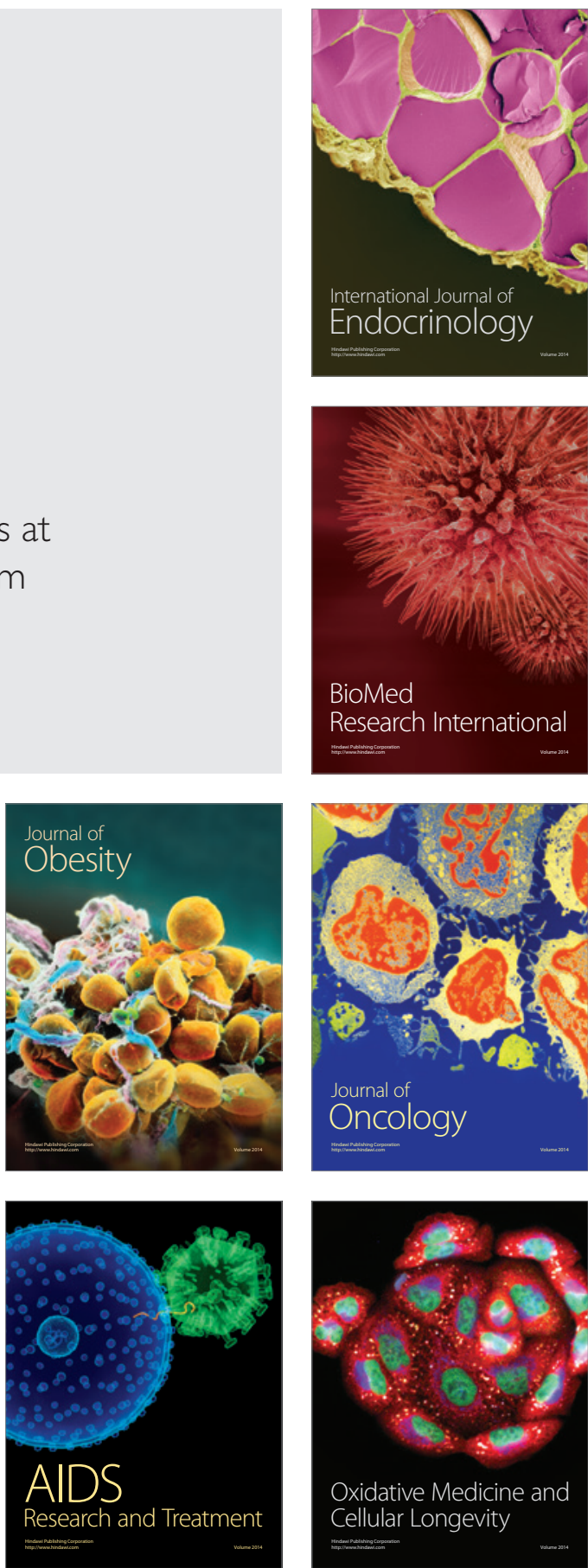